\title{
Multicriteria comparative analysis of pillars strengthening of the historic building
}

https://doi.org/10.1515/eng-2019-0003

Received April 27, 2018; accepted October 4, 2018

\begin{abstract}
Over time, historic buildings are exposed to various destructive mechanisms brought about by a wide range of damaging factors. Costs and methods of reinforcing their individual components are, among others, an important issue. The term "reinforcement" is linked with the concept of conservation, which stands for the actions taken with the aim of preserving a building. It provides a well-articulated system consisting of activities that lead to the reinforcement of the structure, usability enhancement or to the improvement of its carrying capacity. This article analyses the selection of an appropriate brick pillar reinforcement method, taking into account accepted evaluation criteria.
\end{abstract}

\section{Introduction}

The need to preserve the cultural heritage has led to the developement of the area of historical site conservation, including the search for and improvement of ways to strengthen the historical building, or its individual elements. The historical building, in accordance with legal regulations $[1,2]$ denotes a building covered by the following forms of monument protection: entry in the list of historical sites; recognition as a historical site; creation of a cultural park; setting conservation protection requirements in the local spatial development plan. The term "reinforcement" is indirectly related to conservation, that is a process aimed at maintaining the object in a greater than ever durability. It forms a coherent mechanism with actions leading to the strengthening of the structure, striving for the correctness of use, increasing its load capacity, avoiding accidents or preventing future failures.

\footnotetext{
*Corresponding Author: Katarzyna Kafel: Cracow university of technology Cracow, Poland, E-mail: kkafel@l3.pk.edu.pl

Agnieszka Leśniak, Krzysztof Zima: Cracow university of technology Cracow, Poland
}

The reasons and methods of reinforcement of masonry structures have been specified in [3], in which the authors describe methods of repairs allowing further functioning of historical buildings. The techniques presented in [3] use additional reinforcing steel and reinforced concrete elements. Strengthening of reinforced concrete skeletons using steel supports was presented in [4]. The choice of stiffness and durability of the frames was assessed by modelling and verification of calculations. The subject of strengthening reinforced concrete constructions was also discussed in [5], on the example of existing prefabricated beam-pillar connectors. Nowadays, the use of composite materials such as fibre reinforced polymers in strengthening and repairing of structural elements is widely spreading. Authors of the publication [6] presented in their work flexural strengthening of concrete beams using CFRP and GFRP. The numerous ways of reinforcing the structural elements of historical buildings require appropriate selection and then a well-argued choice. For the investment to be a success it is important to properly prepare the preliminary stages - with focus on the preparation of the construction works. The decisions made at these stages may affect the entire investment process both in substantive and financial terms [7]. In order to support decision-making at the initial stage (preliminary stages), multicriteria analysis methods may be useful. They have a number of advantages [8]: they allow the adoption of a large number of criteria for the assessment; they clearly choose the best variant, they objectify expert assessments and their computational algorithms are not difficult to implement in a computer. There are many tools for multi-criteria support of the decision-making process, and the possibilities of their widespread use in construction have been presented in literature, including: [9-14]. The application of multicriteria analysis methods enables the selection of the variant best suited to the preferences of the contractor, with the simultaneous ranking of the decision variants under consideration pillar reinforcement options from the best to the worst.

The aim of the paper is to choose the method of reinforcing brick pillars constituting structural elements of historical building using the multi-criteria analysis 
method. Two types of reinforcements were proposed as reinforcement options: a steel clamp and a reinforced mortar clamp.

\section{Analyzed variants of reinforcement of historical brick pillars}

Building constructions that were created many years ago are exposed to all destructive mechanisms over time. In other words, they have a broad base of destructive factors. From wrong construction solutions, incorrect load distribution, thermal and climatic factors, loss of ground stability, extreme factors, to adaptive, urban-based and unforeseen increase in loads. Negative effects are also exerted by poor water conditions, swelling soil and the proximity of mining facilities. The effects are associated with numerous shocks and vibrations, or other dynamic influences, such as the movements of cars, trains, industrial machines and construction works.

Structural elements, such as pillars, if they are so damaged that they cannot transfer heavy loads, should be completely removed and replaced with new elements. Yet in special cases, this may prove impossible, for example, for conservation reasons. In this case, the defective element should be reinforced with the auxiliary structure.

One of the common methods of reinforcing brick pillars is the use of a clamp [15]. Two types may be distinguished depending on the material from which it is made [15]: a clamp made of mortar reinforced with stirrups or a steel clamp made of flat bars (Fig. 1).
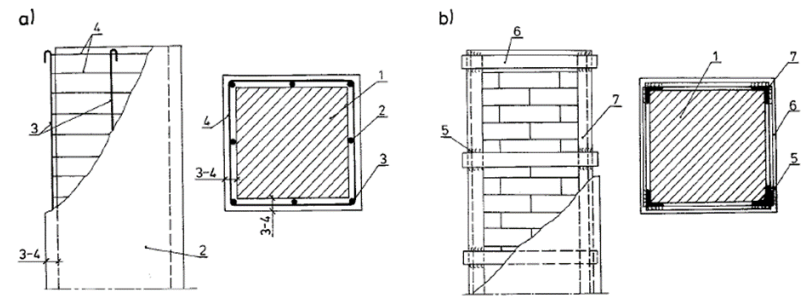

Figure 1: Clamps used in brick column reinforcement: a) reinforced mortar clamp; b) steel clamp [15] where: 1 - reinforced column; 2cement mortar; 3- reinforcement; 4- reinforcement; 5- grout; 6steel flat bar; 7- angle bar

For calculation purposes, the authors adopted the parameters of a historical building, whose structural element - a pillar (two variants) - required reinforcement. One of them is made of class 10 brick, the other of class 8 concrete blocks. Square cross-sections of $70 \times 70$ centimeters and an axial load acting with a force of $\mathrm{N}$ equal to $900 \mathrm{kN}$ were assumed for both pillars. The assumed height of the pillars is 3 meters.

Variant 1. Reinforced mortar clamp intended for the reinforcement of pillars on which loads not causing significant loss of structural load-bearing capacity work. It is usually used in poles with regular cross-section shapes, such as square, rectangle or circle [15]. The relatively small thickness of the clamp used in the reinforcement is its great advantage.

Variant 2. A steel clamp is used for the reinforcement of pillars on which loads causing significant loss of structural load-bearing capacity work. An important thing that should not be overlooked is the uneconomical nature of the described solution [15]. The designed reinforcement uses vertical angles ( $50 \times 50 \times 5$ millimetres) and flat bars $(50 \times 5$ millimetres) placed every 50 centimetres. The steel clamps must be protected against corrosion. For this purpose, a recessed net is used, and then a $3 \mathrm{~cm}$ thick cement mortar is applied. This solution was adopted in the example under consideration. Alternatively, one can also apply pre-compression of angles by heating them to a temperature of about $100{ }^{\circ} \mathrm{C}[15]$.

It is worth noting that the above solutions are unacceptable by monument conservators because they significantly interfere with the cross-sectional area of the pillar and they hinder transverse deformations of the squeezed cross-section, so their load capacity increases $[15,16]$. They also affect the aesthetics of the pillar, which is a particularly important issue in historic buildings.

\section{Multi-criteria comparative analysis}

The aim of the analysis is to select the most beneficial solution to reinforcing the brick pillar as a structural element of the historic building. Among the methods of multicriteria comparative analysis, one can distinguish a group of algorithms consisting in the construction of a scalar whose numerical value is a synthetic index of assessment - the so-called "Mathematical methods" [17]. Among the methods of multicriteria comparative analysis, one can distinguish a group of algorithms describing the construction of a scalar whose numerical value is a synthetic index of assessment - the so-called "Mathematical methods" [17]. Among the existing formulas of synthetic evaluations described, for instance in [17]. The authors chose and ap- 
plied: a revised summative index, a revised additive index and a weighted arithmetic mean.

The output data for the given analysis includes the materials from which the pillars were made, dimensions (height and cross-section), as well as the given load presented in Chapter 2. The costs of reinforcement in the two options under consideration were also calculated: the reinforcement mortar and the steel clamp, as well as the cost of demolition and reconstruction of poles.

The first stage of applying the multi-criteria analysis method involved the selection of criteria. Five criteria for the evaluation of variants were proposed: the cost of implementing the variant, the cost of demolition and reconstruction to the costs of pillar reinforcement, the impact on visual aesthetics and the method of assembly and durability. Using synthetic assessment indices, it is necessary to divide the criteria into stimulants - remaining in a positive correlation with the dependent variable, and destimulants - with a negative correlation. The division of the accepted criteria into stimulants and destimulants is presented in Table 1.

The cost criterion includes the calculation of the cost of constructing the clamps together with securing the construction site and the ceiling structure during the construction works [15]. The bill of quantities which is the basis for cost estimation was made and the following assumptions for the calculation were adopted: the cost of labour cost estimate $15 \mathrm{PLN} / \mathrm{w}-\mathrm{h}$; material prices including purchase costs and equipment prices, as market prices at the level of the third quarter of 2017. Indirect costs were calculated as $69 \%(\mathrm{R}+\mathrm{S})$ and profit as $16 \%(\mathrm{R}+\mathrm{S}+\mathrm{Kp})$. Vat tax was also included. The values are summarized in Table 2.

The second criterion is the ratio of the costs of demolition and reconstruction to the costs of pillar reinforcement, expressed as a percentage. For this purpose, the costs of possible demolition and reconstruction of the original form of pillars were estimated, and then the given value was compared with the costs of reinforcing the pillars made of reinforced mortar and steel clamp. In both cases, the cost ratio exceeded $100 \%$ of the gain value. The values are summarized in Table 3.

Another criterion involves the impact on visual aesthetics, that is the interference in the form and shape. Such features are difficult to describe explicitly because they are based on the definition of art, which for conservators is a concept frequently impossible to define precisely. The authors have attempted an objectified assessment of the difference in the appearance with a designed reinforcement in relation to the original form. Strengthening with the use of a steel clamp interferes with the pillar's appearance more than strengthening with a reinforced mortar clamp.
The employed method in the end results in a bigger crosssection of the reinforced pillar, compared to a pillar reinforced with mortar, due to the use of additional angle bars and grids prior to plastering. The Authors applied a percentage scale to the assessment of variants; their values are presented in Tables 4-6.

The "assembly method" criterion takes into account the following features: labour intensity, level of complexity of works, required qualifications and skills of those performing construction works. The assessment values of the criterion expressed in [\%] are summarized in Table 5.

The last criterion is the "durability” of the designed reinforcement. It considers resistance to damaging factors which lead to the deterioration of properties of the used type of reinforcement (clamp). Maintenance of the required features of its carrying capacity is the key issue of this criterion. The assessment values of the criterion expressed in [\%] are summarized in Table 6.

At a later stage it was necessary to define the order of importance of the respective criteria (Table 7). The authors assessed the criteria importance on the basis of the pair analysis method described in detail in [17]. The authors have set the weight values by the creation of an array, in which value „1" means that the criterion in the verse is more important than the criterion in the corresponding column, while in other cases the value is set to „0" [17]. Adopted criteria weights have been presented in Table 7.

For the comparison and variant evaluation to be possible, adopted criteria assessments need to be given numbers without units. This allows for not only quantitative, but also qualitative features to be compared. Converting dimensional quantities into dimensionless quantities can be called encoding [17]. According to [17], encoding is to be understood as the replacement of the original molecular measure value (dimensional) with a numerical value (dimensionless) from a specified interval, most commonly $(0,1)$ or $\langle 0,1\rangle$. In the study, popular and easily applied mathematical methods of project solution evaluation leading to a structured set of examined variants irrespective of the number of criteria, have been used. They allow for an analysis of any variants under any number of criteria. These methods require the codification of variant values in accordance with a set of features and calculations of their synthetic evaluations [17]. The authors have used two methods of encoding: standarization (Table 8) and Neumann-Morgenstern encoding (Table 9). Standarisation - this method might yield negative variant values and Morgenstern's- positive values. Their detailed description can be found in [17]. 
Table 1: Division of criteria into stimulants and destimulants (own studies)

\begin{tabular}{lc}
\hline \multicolumn{1}{c}{ Criteria } & Type \\
\hline 1. The cost [PLN] & destimulant \\
2. The cost of demolition and reconstruction to the costs of pillar reinforcement [\%] & destimulant \\
3. The impact on visual aesthetics [\%] & stimulant \\
4. The method of assembly [\%] & stimulant \\
5. The durability [\%] & stimulant \\
\hline
\end{tabular}

Table 2: Values for the criterion: costs of the implementation of pillar reinforcement (own studies)

\begin{tabular}{lcc}
\hline & Reinforced mortar clamp & A steel clamp \\
\hline The cost $[\mathrm{PLN}]$ & 2837 PLN & 3267 PLN \\
\hline
\end{tabular}

Table 3: Values for the criterion: the ratio of demolition and reconstruction costs to pillar reinforcement costs (own studies)

\begin{tabular}{lcc}
\hline & Reinforced mortar clamp & A steel clamp \\
\hline $\begin{array}{l}\text { The cost of demolition and reconstruction to the } \\
\text { costs of pillar reinforcement [\%] }\end{array}$ & $133 \%$ & $157 \%$ \\
The cost of demolition and reconstruction [PLN] & 3773 PLN & 5113 PLN \\
\hline
\end{tabular}

Table 4: Values for the criterion: impact on visual aesthetics (own studies)

\begin{tabular}{lc}
\hline \multicolumn{1}{c}{ The impact on visual aesthetics } & $\begin{array}{c}\text { Criteria } \\
\text { values for } \begin{array}{c}\text { Criteria } \\
\text { values for } \\
\text { a steel } \\
\text { clamp } \\
\text { reinforced } \\
\text { mortar } \\
\text { clamp }\end{array}\end{array}$ \\
$\begin{array}{l}\text { 1. The Significance difference in the appearance with the original } \\
\text { form }\end{array}$ & $\begin{array}{c}(0 \%, 25 \%) \\
\text { 2. The average difference in the appearance with the original form }\end{array}$ \\
$\begin{array}{l}\text { 3. The little difference in the appearance with the original form } \\
\text { 4. No difference in the appearance with the original form }\end{array}$ & $\begin{array}{c}(51 \%, 75 \%) \\
(76 \%, 100 \%)\end{array}$ \\
\hline
\end{tabular}

Table 5: Values for the criterion: impact on visual aesthetics (own studies)

\begin{tabular}{lccc}
\hline \multicolumn{1}{c}{ Assembly method } & Range [\%] & $\begin{array}{c}\text { Criteria values for a } \\
\text { reinforced mortar } \\
\text { clamp }\end{array}$ & $\begin{array}{c}\text { Criteria } \\
\text { values for a } \\
\text { steel clamp }\end{array}$ \\
\hline $\begin{array}{l}\text { 1. Very complicated, time-consuming } \\
\text { 2. Moderate difficulty }\end{array}$ & $(0 \%, 25 \%)$ & & $40 \%$ \\
3. Easy & $(26 \%, 50 \%)$ & $50 \%$ & \\
4. Very easy & $(51 \%, 75 \%)$ & & \\
\hline
\end{tabular}

\section{Analysis of obtained results}

At the last stage of the performed analysis a revised summative index (formula 1), a revised additive index (formula 2) and a weighted arithmetic mean (formula 3) are determined [17].
Revised summative index:

$$
J_{i}=\sum_{j=1}^{m}\left(z_{i j} \cdot v_{j}\right)
$$

Revised additive index:

$$
J_{i}=\frac{1}{m} \sum_{j=1}^{m}\left(z_{i j} \cdot v_{j}\right)
$$


Table 6: Values for criterion: reinforcement durability (own studies)

\begin{tabular}{lccc}
\hline \multicolumn{1}{c}{ Reinforcement durability } & Range [\%] & $\begin{array}{c}\text { Criteria values } \\
\text { for a reinforced } \\
\text { mortar clamp }\end{array}$ & $\begin{array}{c}\text { Criteria values } \\
\text { for a steel } \\
\text { clamp }\end{array}$ \\
\hline $\begin{array}{l}\text { 1. Low durability } \\
\text { 2. Moderately durable }\end{array}$ & $(0 \%, 25 \%)$ & & $70 \%$ \\
3. Durable, resistant to destructive agents & $(26 \%, 50 \%)$ & $45 \%$ & \\
4. Highly resistant to destructive agents & $(51 \%, 75 \%)$ & & \\
\hline
\end{tabular}

Table 7: Criteria weight values (own studies)

\begin{tabular}{|c|c|c|c|c|c|c|c|}
\hline \multicolumn{8}{|c|}{ Criterion } \\
\hline Criterion & $\begin{array}{l}1 . \\
\text { Cost }\end{array}$ & $\begin{array}{c}2 . \\
\text { Cost of recon- } \\
\text { struction/ cost } \\
\text { of } \\
\text { reinforcement } \\
\text { ratio }\end{array}$ & $\begin{array}{c}3 . \\
\text { Effects on } \\
\text { visual } \\
\text { aesthet- } \\
\text { ics }\end{array}$ & $\begin{array}{l}4 . \\
\text { Installation } \\
\text { method }\end{array}$ & $\begin{array}{c}5 . \\
\text { Reinforcement } \\
\text { durability }\end{array}$ & Total & Weight \\
\hline $\begin{array}{l}\text { 1. Cost } \\
\text { 2. Cost of }\end{array}$ & 1 & 1 & 1 & 1 & 1 & 5 & 0,33 \\
\hline $\begin{array}{l}\text { reconstruction/cost of } \\
\text { reinforcement ratio }\end{array}$ & 0 & 1 & 0 & 0 & 0 & 1 & 0,07 \\
\hline $\begin{array}{l}\text { 3. Effects on visual } \\
\text { aesthetics }\end{array}$ & 0 & 1 & 1 & 1 & 1 & 4 & 0,27 \\
\hline 4. Installation method & 0 & 1 & 0 & 1 & 0 & 2 & 0,13 \\
\hline \multirow[t]{2}{*}{ 5. Reinforcement method } & 0 & 1 & 0 & 1 & 1 & 3 & 0,20 \\
\hline & & & & & Total & 15 & 1,00 \\
\hline
\end{tabular}

Table 8: Values calculated with the standarization method (own studies)

\begin{tabular}{lccccc}
\hline \multicolumn{1}{c}{$\begin{array}{c}\text { Standarization } \\
\text { method encoding }\end{array}$} & \multicolumn{4}{c}{ Criterion } \\
\cline { 2 - 6 } & Cost & $\begin{array}{c}\text { Inhibiting factors } \\
\text { reconstruction/cost } \\
\text { of reinforcement ratio }\end{array}$ & $\begin{array}{c}\text { Cost of } \\
\text { visual } \\
\text { ics }\end{array}$ & $\begin{array}{c}\text { Sthet } \\
\text { ictallation } \\
\text { method }\end{array}$ & $\begin{array}{c}\text { Reinforcement } \\
\text { durability }\end{array}$ \\
$\begin{array}{l}\text { 1. Reinforced mortar } \\
\text { clamp }\end{array}$ & 1 & 1 & 1 & 1 & -1 \\
2. Steel clamp & -1 & -1 & -1 & -1 & 1 \\
\hline
\end{tabular}

Weighted arithmetic mean:

$$
J_{i}=\frac{\sum_{j=1}^{m}\left(z_{i j} \cdot v_{j}\right)}{\sum_{j=1}^{m}\left(v_{j}\right)}
$$

where:

$J_{i}$ - synthetic evaluation of the i-th variant,

$m$ - number of criteria,

$z_{i j}$ - encoded measure of the $\mathrm{i}$-th variant in relation to the

$\mathrm{j}$-th criterion,

$v_{j}-\mathrm{j}$-th criterion weight.
Result and synthetic evaluation summary for the standarization method encoding has been summed-up in Tables 10, 11.

Result and synthetic evaluation summary for encoding with the von Neumann - Morgenstern method, summed-up in Tables 12, 13.

Comparison of synthetic measure values for respective variants according to the encoding method used has been presented in Fig. 2, Fig 3. 
Table 9: Values calculated with the von Neumann - Morgenstern encoding method (own studies)

\begin{tabular}{|c|c|c|c|c|c|}
\hline \multirow{3}{*}{$\begin{array}{l}\text { von Neuman- } \\
\text { Morgenstern } \\
\text { encoding }\end{array}$} & \multicolumn{5}{|c|}{ Criterion } \\
\hline & \multicolumn{2}{|c|}{ Inhibiting factors } & \multicolumn{3}{|c|}{ Stimulating factors } \\
\hline & Cost & $\begin{array}{c}\text { Cost of } \\
\text { reconstruction/cost } \\
\text { of reinforcement } \\
\text { ratio }\end{array}$ & $\begin{array}{l}\text { Effects on } \\
\text { visual } \\
\text { aesthet- } \\
\text { ics } \\
\end{array}$ & $\begin{array}{l}\text { Installation } \\
\text { method }\end{array}$ & $\begin{array}{c}\text { Reinforcement } \\
\text { durability }\end{array}$ \\
\hline $\begin{array}{l}\text { 1. Reinforced mortar } \\
\text { clamp }\end{array}$ & 1,0 & 1,0 & 1,0 & 1,0 & 0,0 \\
\hline 2. Steel clamp & 0,0 & 0,0 & 0,0 & 0,0 & 1,0 \\
\hline
\end{tabular}

Table 10: Results of the standarization method calculations (own studies)

\begin{tabular}{|c|c|c|c|c|c|}
\hline \multirow[t]{3}{*}{ Solution } & \multicolumn{5}{|c|}{ Criterion } \\
\hline & \multicolumn{2}{|c|}{ Inhibiting factors } & \multicolumn{3}{|c|}{ Stimulating factors } \\
\hline & $\begin{array}{c}\text { Cost } \\
\text { weight: } \\
0,33\end{array}$ & $\begin{array}{l}\text { Cost of } \\
\text { reconstruction/ } \\
\text { cost of } \\
\text { reinforcement } \\
\text { ratio weight: } 0,07\end{array}$ & $\begin{array}{l}\text { Effects on } \\
\text { visual } \\
\text { aesthetics } \\
\text { weight: } \\
0,27\end{array}$ & $\begin{array}{c}\text { Installation } \\
\text { method } \\
\text { weight: } \\
0,13\end{array}$ & $\begin{array}{c}\text { Reinforcement } \\
\text { durability } \\
\text { weight: } 0,20\end{array}$ \\
\hline $\begin{array}{l}\text { 1. Reinforced } \\
\text { mortar clamp }\end{array}$ & 0,333 & 0,067 & 0,267 & 0,133 & $-0,200$ \\
\hline 2. Steel clamp & $-0,333$ & $-0,067$ & $-0,267$ & $-0,133$ & 0,200 \\
\hline
\end{tabular}

Table 11: Synthetic evaluation summary (standarization method encoding) (own studies)

\begin{tabular}{lccc}
\hline \multicolumn{1}{c}{ Reinforcement type } & $\begin{array}{c}\text { Revised summative } \\
\text { index }\end{array}$ & $\begin{array}{c}\text { Revised additive } \\
\text { index }\end{array}$ & $\begin{array}{c}\text { Weighted } \\
\text { arithmetic mean }\end{array}$ \\
\hline 1. Reinforced mortar clamp & 0,600 & 0,130 & 0,600 \\
2. Steel clamp & $-0,600$ & $-0,130$ & $-0,600$ \\
\hline
\end{tabular}

Table 12: Synthetic evaluation summary (von Neumann - Morgenstern method) (own studies)

\begin{tabular}{lccccc}
\hline \multirow{2}{*}{ Solution } & \multicolumn{5}{c}{ Criterion } \\
\cline { 2 - 6 } & \multicolumn{3}{c}{ Inhibiting factor } & \multicolumn{3}{c}{ Stimulating factor } \\
\cline { 2 - 6 } & $\begin{array}{c}\text { Cost } \\
\text { weight: }\end{array}$ & $\begin{array}{c}\text { reconstruction/ } \\
\text { cost of }\end{array}$ & $\begin{array}{c}\text { Effects on } \\
\text { visual } \\
\text { aesthetics }\end{array}$ & $\begin{array}{c}\text { Installation } \\
\text { method }\end{array}$ & $\begin{array}{c}\text { Reinforcement } \\
\text { durability }\end{array}$ \\
1. Reinforced & 0,33 & reinforcement & weight: & weight: & weight: 0,20 \\
mortar clamp & 0,333 & 0,067 & 0,27 & 0,13 & 0,000 \\
2. Steel clamp & 0,000 & 0,000 & 0,000 & 0,000 & 0,200 \\
\hline
\end{tabular}

Table 13: Synthetic evaluation summary (von Neumann - Morgenstern method) (own studies)

\begin{tabular}{lccc}
\hline Reinforcement type & $\begin{array}{c}\text { Revised summative } \\
\text { index }\end{array}$ & $\begin{array}{c}\text { Revised additive } \\
\text { index }\end{array}$ & $\begin{array}{c}\text { Weighted } \\
\text { arithmetic mean }\end{array}$ \\
\hline 1. Reinforced mortar clamp & 0,800 & 0,160 & 0,800 \\
2. Steel clamp & 0,200 & 0,040 & 0,200 \\
\hline
\end{tabular}




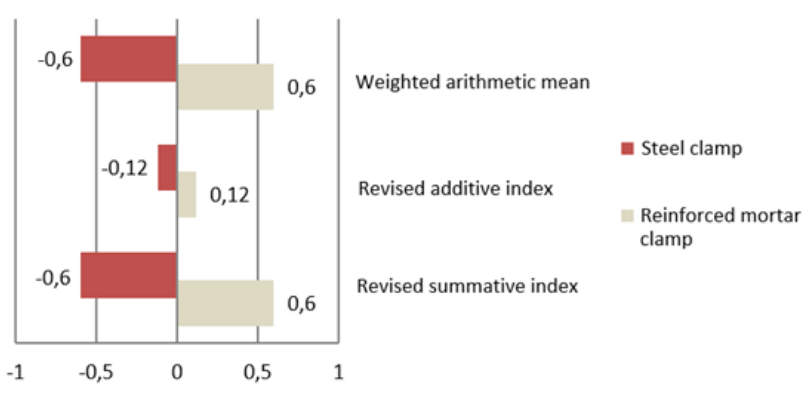

Figure 2: Comparison of synthetic measure values for standarization (own studies)

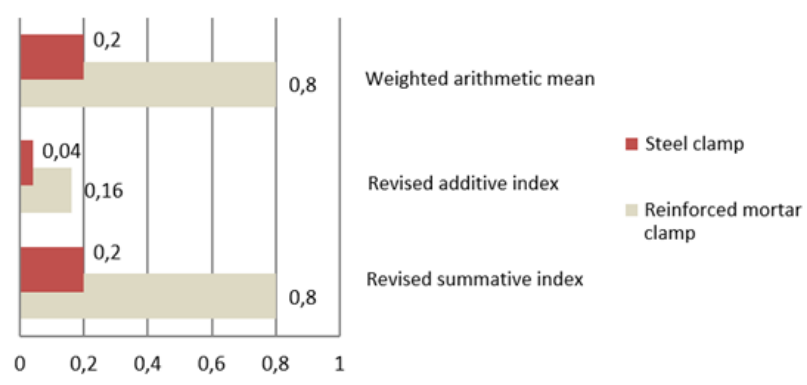

Figure 3: Comparison of synthetic measure values for encoding with the von Neumann - Morgenstern method (own studies)

The results of synthetic measure values for respective variants indicated that strengthening with reinforced mortar is a more favorable solution than the variant using a steel clamp.

\section{Conclusions}

The way in which a given historical construction element is reinforced depends on many factors: the type of damage and the past of the building's functioning, its further use, load capacity requirements and, above all, the material from which it was made. The need for the reconstruction of historical buildings was justified by the authors: [18], assessing the hierarchy of priorities in the decision-making process related to the necessity of repair, taking into account the archaeological, economic, social and historical features of the buildings. In the present paper, a multicriteria analysis method was successfully applied to the price of reinforcement options for brick pillars. As a result of pair comparisons of the adopted evaluation criteria, a hierarchy of weight importance of individual criteria was defined. "Cost" proved to be the most significant criterion. It depends mainly on the building materials used during the reinforcement of the structure, their quantity and the required quality (specific technical parameters).
The second criterion in the hierarchy of importance was the impact on visual aesthetics. It is important due to the historical character of the structural element and the frequently demanding conservation requirements, which are often very restrictive. The criterion: the profitability of demolition and total reconstruction was of the least importance. The main assumption was to maximize the chances of preserving the structural element in the form least different from the original.

The results of the analysis obtained indicated that strengthening with reinforced mortar is a more favorable solution (higher values of synthetic evaluation indicators) than the variant using a steel clamp. For all three indicators of the synthetic assessment, the result was the same regardless of the coding method used.

Finally, it is worth emphasizing that the more advantageous version of pillar reinforcement is at the same time a cheaper option. This confirms the validity of the use of multi-criteria analysis and the introduction of additional criteria for assessing the options considered beyond the cost criterion, which is most frequently used by both contractors and investors.

\section{References}

[1] Regulation of the Minister of Infrastructure of 30 August 2004 on the conditions and procedure for dealing with the demolition of unused or unfinished construction works (Journal of Laws 2004 No. 198 item 2043)

[2] The Act of 7 July 1994 - Polish Construction Law (Journal of Laws of 2017 item 1202, 1276

[3] Rucka M., Zielińska M., Wybrane metody wzmacniania ceglanych obiektów zabytkowych, 2017, Materiały Budowlane 11/2017: 29-30

[4] Khalili A., Kheyroddin A, Sharbatdar M. M., Farahani A., Study on the nonlinear behavior of strengthened RC frames using steel prop and crub in connections and strengthening of beam and column, JOURNAL OF MODELING IN ENGINEERING, 2016, 14/46: 25-38

[5] Yousef A. Al-Salloum, Mohammed A. Alrubaidi, Hussein M. Elsanadedy, Tarek H. Almusallam, Rizwan A. Iqbal., Strengthening of precast RC beam-column connections for progressive collapse mitigation using bolted steel plates, Engineering Structures, 2018, 161:146-160

[6] Attari N., Amziane S., Chemrouk M., Flexural strengthening of concrete beams using CFRP, GFRP and hybrid FRP sheets, Construction and Building Materials, 2012, 37: 746-757

[7] Lendo-Siwicka M., Połoński M., Pawluk K., Identification of the interference in the investment process during the realization of a shopping centre - a case study, Archives of Civil Engineering, 2016, tom LXII, 1/2016: 159-172

[8] Velasquez, M., Hester P. T., An analysis of multi-criteria decision making methods, 2013, International Journal of Operations Re- 
search, 10(2), 56-66

[9] Radziejowska, A., Zima, K., Multicriteria analysis in selecting the optimal variant of solar system, In E3S Web of Conferences, EDP Sciences, 2016, Vol. 10, p. 00078

[10] Krzemiński, M., Comparison of selected multi-criteria assessment methods. In AIP Conference Proceedings, AIP Publishing, 2016, Vol. 1738, No. 1, p. 200004

[11] Leśniak A., Radziejowska A., Supporting bidding decision using multi-criteria analysis methods, Procedia Engineering, 2017, tom 208: 76-81

[12] Sobotka, A., Rolak, Z., Multi-attribute analysis for the ecoenergetic assessment of the building life cycle, Technological and Economic Development of Economy, 2009, 15(4), 593-611

[13] Książek, M., Nowak, P., Rosłon, J., Wieczorek, T., Multicriteria assessment of selected solutions for the building structural walls, Procedia Engineering, 2014, 91, 406-411
[14] Leśniak, A., Balicki, J., Selection of Façades Finishing Technology for a Commercial Building Using Multi-Criteria Analysis. Entrepreneurial Business and Economics Review, 2016, 4(2), 67-79

[15] Masłowski E., Spiżewska D., Wzmacnianie konstrukcji budowlanych, Arkady, Warszawa, 2000

[16] PN-87/B-03002 : Konstrukcje murowe. Obliczenia statyczne i projektowanie

[17] Szwabowski J., Deszcz J., Metody wielokryterialnej analizy porównawczej. Wydawnictwo Politechniki Śląskiej, 2001

[18] Kutut V., Zavadskas E., Lazauskas M., Assessment of priority alternatives for preservation of historic buildings using model based on ARAS and AHP methods, Archives of Civil and Mechanical Engineering, 2014, 14/2:287-294 